\title{
GOOGLE DRIVE FOR STORING ARCHIVES MENGOPTIMASI PENGGUNAAN GOOGLE DRIVE SEBAGAI TEMPAT PENYIMPANAN ARSIP BAGI PELAJAR
}

\author{
Anisa Ni'matussholihal
}

\begin{abstract}
Abstrak
Arsip merupakan dokumen yang digunakan untuk membuat keputusan yang tepat dalam berkomunikasi dengan orang lain berdasarkan memori yang telah ada. Dengan demikian, pengelolaan arsip harus mudah ditemukan, sederhana, dan aman. Perkembangan ilmu pengetahuan dan teknologi saat ini menyebabkan perubahan dalam bidang pendidikan terutama bagi para pelajar, begitu pula pada arsip yang dahulunya merupakan arsip bermedia kertas namun sekarang berkembang menjadi arsip yang medianya tersaji dalam bentuk media baru seperti film, kaset, video, elektrik, $C D, D V D$, flashdisk, hard disk, dan lainlain. Masih banyak persoalan dalam hal pengelolaan dan penyimpanan arsip bagi pelajar, sehingga perlu adanya tempat penyimpanan secara retrieval system, salah satunya adalah dengan menggunakan Google Drive.
\end{abstract}

Kata kunci: arsip, google drive, retrieval system

\section{A. Pendahuluan}

Pengertian arsip menurut Undang-Undang Nomor 43 Tahun 2009 tentang Kearsipan adalah rekaman kegiatan atau peristiwa dalam berbagai bentuk dan media sesuai dengan perkembangan teknologi informasi dan komunikasi yang dibuat dan diterima oleh lembaga negara, pemerintahan daerah, lembaga pendidikan, perusahaan, organisasi politik, organisasi kema s yarakat a n, d a n perseorangan dalam pelaksanaan kehidupan bermasyarakat, berbangsa, dan bernegara.
Perkembangan ilmu pengetahuan dan teknologi saat ini menyebabkan perubahan bentuk arsip. Arsip yang dahulunya bermedia kertas, sekarang berkembang menjadi arsip yang medianya tersaji dalam bentuk media baru seperti: film, kaset, video, elektrik, $C D, D V D$, flashdisk, harddisk, dan lain-lain. Saat ini banyak pelajar yang menggunakan media elektronik dalam pengelolaan dokumen yang dimilikinya. Adanya arsip tidak akan terlepas dari kegiatan atau peristiwa yang dilakukan oleh pelajar. Pelajar memiliki berbagai

Pelajar SMA Negeri 2 Wonosari 
arsip yang berkaitan dengan pelajaran sekolah misalnya materimateri pelajaran, latihan-latihan soal, buku elektronik, makalah atau proposal, dan tugas-tugas sekolah yang diarsipkan. Tujuan pelajar mengarsipkan file-file tersebut adalah untuk memudahkan kembali saat ingin digunakan kembali, sebab file-file pelajaran tersebut masih digunakan saat menghadapi Ujian Nasional.

Penyimpanan arsip yang dilakukan oleh pelajar masih kurang efisien sebab masih disimpan dalam laptop atau netbook. Padahal risiko kehilangan file-file tersebut cukup besar. Misalnya laptop atau netbook tersebut rusak, hilang atau terkena virus. Selain itu penyimpanan arsip melalui laptop atau netbook tidak bisa dibuka tanpa menggunakan alat yang sama. Sehingga arsip tersebut tidak bisa dibuka kapan saja dan dimana saja. Dengan adanya hal tersebut maka perlu adanya aplikasi untuk memudahkan penyimpanan arsip yang berbentuk file untuk mencegah terjadinya kerusakan atau kehilangan arsip. Salah satunya adalah dengan menggunakan media elektronik yang diharapkan dapat membantu pihak pengelola arsip untuk dapat mengelola arsipnya secara efektif dan efisien.

Google Drive merupakan sebuah layanan tempat penyimpanan data secara online menggunakan akun Gmail. Selain arsip yang berbentuk dokumen, Google Drive juga dapat menyimpan arsip yang berupa video, gambar, musik, PDF dan lain-lain. Selain dapat menyimpan berbagai macam bentuk arsip Google Drive juga bekerja secara retrieval system, yaitu dapat ditemukan kembali serta dapat diakses sewaktu-waktu tanpa memerlukan hardware yang sama pada saat menyimpannya.

\section{B. RumusanMasalah}

Saat ini banyak pelajar yang kurang efektif dalam menyimpan data melalui komputer, netbook ataupun flash disk. Salah satunya adalah saat hardware tersebut terkena virus, sehingga file bisa rusak bahkan hilang. Permasalahan lain adalah saat pelajar ingin membuka file yang telah diarsipkan, apabila tidak membawa hardware yang digunakan untuk menyimpan, file tersebut tidak bisa dibuka. Untuk mengatasi hal tersebut diperlukan suatu aplikasi untuk memudahkan dalam menyimpan arsip yang berupa file. Salah satunya adalah Google Drive. Dengan berbagai aplikasi yang ada pada Google Drive yang sesuai untuk menyimpan arsip, perlu adanya pengembangan penggunaan Google Drive bagi para pelajar. Penulis akan membahas tentang: 
1. B a ga im a n a prins i p menggunakan Google Drive sebagai tempat penyimpanan arsip bagi pelajar?

2. Bagaimanakah tahapantahapan dalam penyimpananan arsip menggunakan Google Drive?

3. Bagaimanakah cara mengelola arsip menggunakan Google Drive?

\section{KerangkaTeori}

\section{Arsip}

Pengertian arsip menurut Undang-Undang Nomor 43 Tahun 2009 tentang Kearsipan adalah rekaman kegiatan atau peristiwa dalam berbagai bentuk dan media sesuai dengan perkembangan teknologi informasi dan komunikasi yang dibuat dan diterima oleh lembaga negara, pemerintahan daerah, lembaga pendidikan, perusahaan, organisasi politik, organisasi kem as y arakata n, d a n perseorangan d a la m pelaksanaan kehidupan bermasyarakat, berbangsa, dan bernegara.

Prinsip yang harus diperhatikan dalam mengelola arsip adalah mudah ditemukan kembali, sederhana, aman, dan murah karena arsip semakin lama akan semakin menumpuk banyak. $^{2}$
B a $\mathrm{n}$ y a $\mathrm{k} \quad \mathrm{s}$ e $\mathrm{k}$ a $1 \mathrm{i}$ permasalahan yang timbul akibat pengelolaan arsip yang kurang efektif, diantaranya adalah:

a. $\mathrm{R} \mathrm{u}$ a n g a n u n t u k menyimpan arsip menjadi semakin penuh sehingga perlu ruangan yang lebih luas.

b. Prasarana yang digunakan untuk menempatkan arsip juga tidak mencukupi.

c. Penemuan kembali arsip yang diperlukan menjadi lebih sulit.

d. Biaya untuk perawatan arsip mahal.

e. Kegiatan organisasi menjadi terhambat, karena keputusan yang diambil tidak bisa dilaksanakan dengan cepat dan tepat. ${ }^{3}$

Untuk mengatasi hal tersebut, manajemen pengolahan arsip harus diterapkan sesuai dengan kondisi organisasi. Manfaat yang dapat diperoleh ketika arsip-arsip organisasi tertata dengan baik adalah:

a. perencanaan untuk program kegiatan yang akan dilaksanakan di masa yang akan datang dapat dibuat berdasarkan kepada evaluasi dari kegiatan yang telah dilaksanakan

b. perlindungan aset terjamin

\footnotetext{
${ }^{2}$ Setyawati Nukuk Dwi Hastuti."Pengelolaan Dokumen”. Buletin Kearsipan Sahifah, 2014, halaman18.

${ }^{3}$ Edar Santoso. “Arsip: From Problem to Solution”. Buletin Kearsipan Sahifah, 2014, halaman 6.
} 
c. perlindungan hak terjamin

d. mengingat proses terciptanya arsip yang independen dan jujur,maka organisasi memiliki sumber informasi yang terperaya dan universal, sedangkan informasi tersebut dapat menjadi aset yang berharga ${ }^{4}$

\section{Google Drive}

Google Drive adalah layanan berbasis komputasi awan yang dapat digunakan untuk membuat, membagi, mengolaborasikan, dan menyimpan data hingga 1 terabite $(T B)$. Menurut perwakilan Google, Sundar Pichai, Drive memungkinkan pengguna mengunggah dan mengakses berbagai file seperti video, foto, Google Docs dan $P D F$. File dapat diakses sewaktu-waktu, di rumah, kantor, atau bahkan saat berada jauh dari perangkat, dengan media penyimpanan berbasis awan ini. Menurutnya, Drive dapat digunakan di komputer Mac dan merek lain. Selain itu, Drive juga bisa digunakan di komputer tablet dan ponsel bersistem operasi Android. Tidak hanya itu, pengguna yang mengalami gangguan penglihatan pun dapat $\mathrm{m}$ e $\mathrm{ng}$ a $\mathrm{ks}$ e $\mathrm{s}$ D rive menggunakan alat pembaca layar (screen reader). Keuntungan penggunaan Google Drive antara lain:

a. $\mathrm{M}$ e mili k i $s p a c e$ penyimpanan yang besar

Google Drive adalah layanan bebas yang menawarkan space hingga 5 $G B$ untuk setiap pengguna Gmail biasa. Dengan hanya memiliki akun Gmail saja sudah akan mendapatkan space $5 G B$ di internet. Space ini dapat di-upgrade hingga $25 G B$ dengan $\mathrm{membay}$ bi a y t a m b a han. Namun demikian, dengan space 5 $G B$ sudah cukup untuk menyimpan banyak file.

b. Media penyimpanan virtual

Misalnya suatu hari laptop rusak atau hilang, pasti data di dalamnya juga ikut hilang. Terkadang data yang hilang jauh lebih penting dari harga laptop itu sendiri. Dengan mengupload data ke Google Drive, berarti telah dilakukan antisipasi backup data penting. Dengan cara ini semua informasi telah disimpan dalam suatu cadangan penyimpanan yang dapat diakses/diambil dari berbagai perangkat, dengan autentikasi tertentu.

Ibid., halaman 6 
c. File support

Google Drive dapat membuka hingga 30 jenis format file yang berbeda ke dalam browser, bahkan ketika perangkat lunak tersebut tidak dipasang pada desktop. Hal ini sangat berguna jika seorang desainer yang biasanya bekerja menggunakan file berukuran besar seperti photoshop atau ilustrasi, sehingga file akan lebih mudah diakses setiap saat.

d. Editfile secara simultan

Google Drive memungkinkan beberapa orang dapat bekerja pada dokumen yang sama dan dapat memodifikasi pada waktu yang sama seolaholah mereka bekerja bersama-sama dalam satu ruangan. Hasil dari kolaborasi ini akan jauh lebih cepat daripada harus bergiliran dalam mengedit dokumen dalam suatu proyek, contohnya: membuat laporan tugas kelompok.

e. Akses di manapun dan kapanpun

$$
\text { Google Drive }
$$
memungkinkan akses file di manapun dan kapanpun, selama ada koneksi internet. Bahkan dengan download tambahan, Google Drive pada browser Google Chrome, dapat mengakses dan mengedit file secara offline. Bila koneksi telah online, modifikasi file akan tersimpan secara otomatis. Google Drive juga tersedia untuk mobile platform seperti Android dan iPhone.

f. Secure sharing

$$
\text { Google Drive }
$$
memungkinkan pengguna berbagi file. Dengan kata lain, Google Drive dapat difungsikan sebagai virtual harddisk. Hanya pemilik akun yang dapat mengakses kontennya. Aktivitas orang lain dapat dibatasi dalam hal edit dan komentar.

g. feedback comments

Sistem thread komentar bertindak sebagai sistem umpan balik aktif untuk mendapatkan pandangan setiap orang mengenai suatu topik/dokumen. Hal ini dapat menjamin pengguna untuk mendapatkan umpan balik yang tepat dari orang lain tentang tentang kebenaran dari topik dan parameter lainnya. 


\section{Kerangka Berpikir}

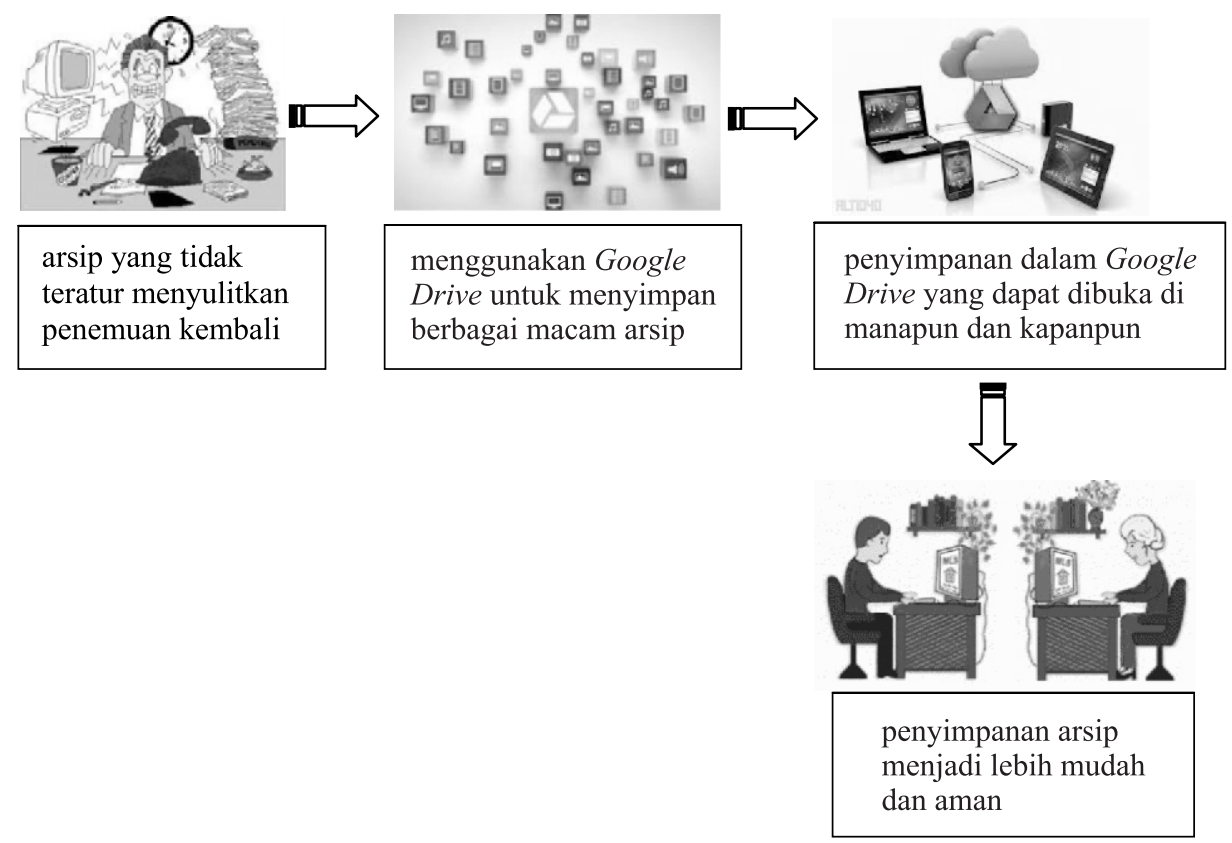

\section{E. Analisis}

Banyak pelajar yang menyimpan arsip-arsip berupa file, namun penyimpanannya kurang efektif dan kurang aman. Pelajar SMA kelas X dan XI banyak menyimpan arsip berupa soal-soal latihan, materi-materi pembelajaran, dan tugas-tugas. Selain itu banyak juga pelajar yang mengikuti berbagai organisasi dan ekstrakurikuler. Misalnya saja dalam organisasi OSIS yang setiap tahun mengadakan berbagai macam kegiatan. Dalam melakukan kegiatan biasanya perlu mengajukan proposal, membuat undangan, dan suratsurat penyelenggaraan kegiatan. Siswa yang mengikuti ekstrakurikuler Kelompok Ilmiah
Remaja (KIR) misalnya, juga memiliki arsip berupa hasil-hasil penelitian yang cukup banyak. Hasil penelitian tersebut biasanya masih sering digunakan untuk kepentingan-kepentingan penelitian selanjutnya, maka perlu adanya penyimpanan arsip yang dapat digunakan kapanpun dan di manapun. Dengan menggunakan Google Drive maka akan membantu pelajar untuk menyimpan arsip-arsip mereka.

Penggunaan Google Drive sebagai tempat penyimpanan arsip bagi pelajar tentu sangat membantu. Untuk meningkatkan pemahaman pelajar tentang penggunaan Google Drive, perlu dipaparkan hal-hal tentang penggunaan Google Drive, 
diantaranya adalah:

1. Prinsip menggunakan Google Drive

Prinsip yang harus dimiliki untuk menggunakan Google Drive adalah memiliki akun Gmail. Selain itu komputer atau hardware yang digunakan harus terkoneksi dengan internet karena Google Drive hanya bisa diakses apabila terkoneksi dengan internet saja. Dari mengunggah arsip, mengunduh arsip, bahkan mengelola file juga perlu terkoneksi dengan internet.

2. $\mathrm{T}$ a h a $\mathrm{p}$ a $\mathrm{n}-\mathrm{t}$ a h a $\mathrm{p}$ a $\mathrm{n}$ menggunakan google drive

a. stimulasi mengunggah file atau arsip

Mengunggah file atau arsip merupakan langkah pertama yang diperlukan untuk menyimpan arsip tersebut. Arsip yang sudah berhasil diunggah akan secara otomatis tersimpan di Google Drive. Berikut merupakan cara-cara mengunggah file:

1) Pertama-tama masuk ke drive.google.com kemudian login dengan akun Google. (gambar 1)

2) Klik tombol baruunggah file - kemudian pilih file yang akan diunggah. (gambar 2)
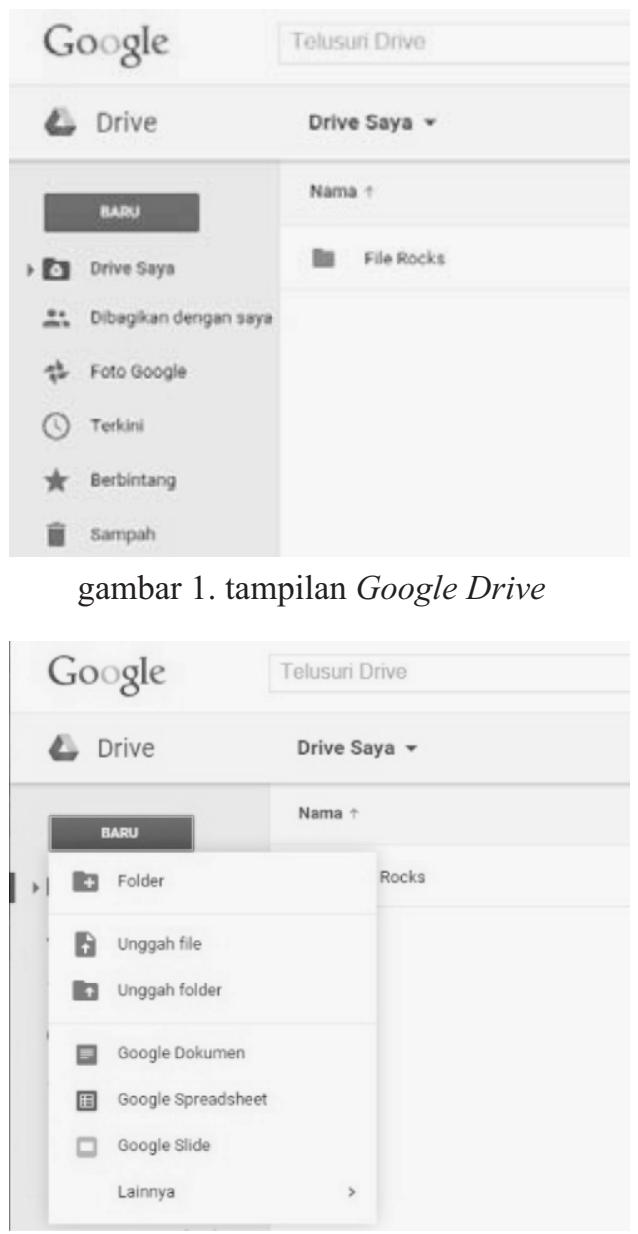

gambar 2. tampilan tombol baru

3) Proses unggah akan muncul di kanan bawah. Apabila sudah muncul tulisan "Sudah diunggah" maka file sudah terunggah secara otomatis.

4) Setelah selesai, klik tombol "Bagikan" di bagian kanan kotak. Atau klik kanan file tersebut di drive kemudian klik: bagikan. (gambar 3) 


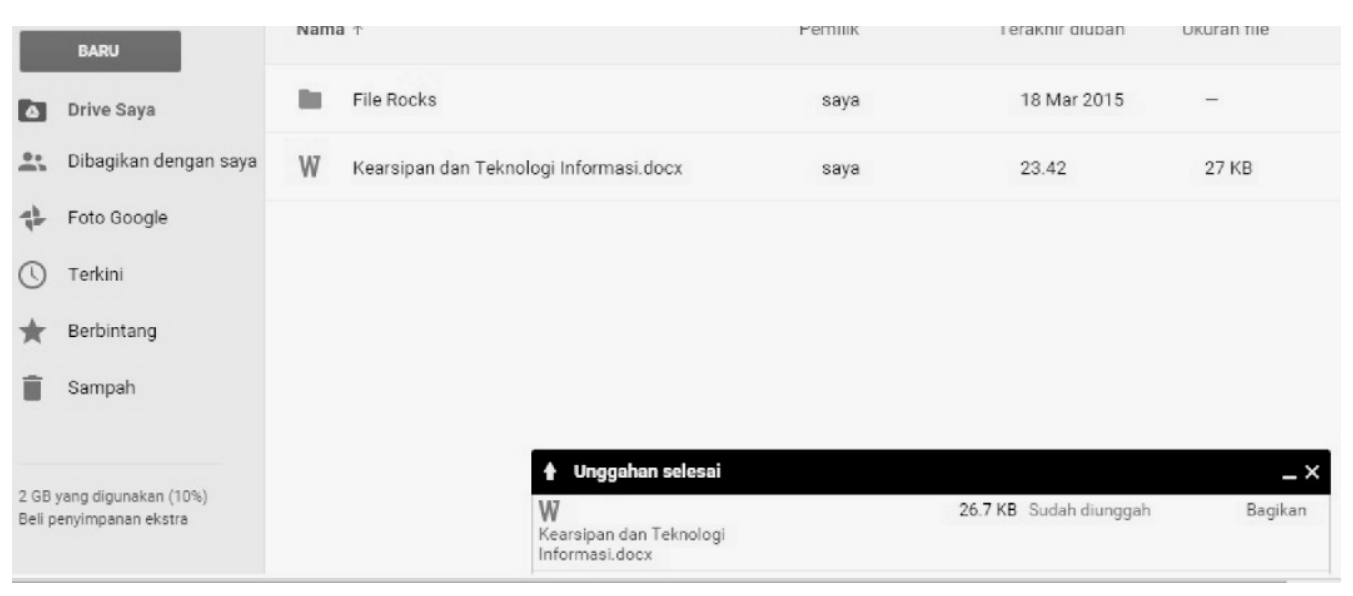

gambar 3. mengunggah file atau arsip ke Google Drive

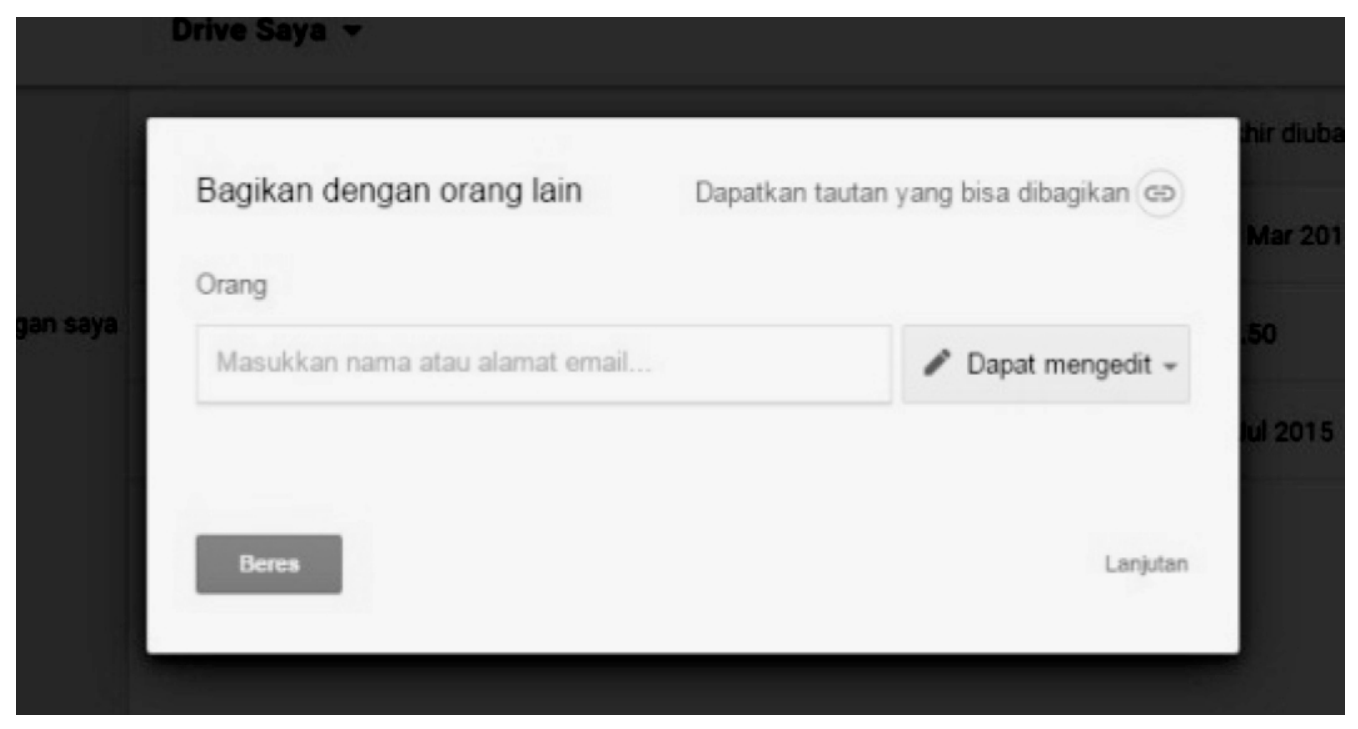

gambar 4. kotak untuk membagikan file atau arsip

5) Kotak share akan muncul, klik di kanan atas "Bagikan dengan orang lain". Akan muncul link untuk dibagikan. (gambar 4) b. Stimulasi pembuatan file melalui Google Drive

Aplikasi yang terdapat dalam Google Drive sangat beraneka ragam yang dapat $\mathrm{m}$ e $\mathrm{mb}$ a n t u d a $1 \mathrm{a} \mathrm{m}$ pembuatan arsip di antaranya: 
Google Drive juga menyediakan beberapa fasilitas untuk membuat file berupa Google Document, Google Spreadsheet, dan Google Slide. (gambar 5)

Google Document digunakan untuk mengolah kata, seperti halnya Ms. Word. Google Spreadsheet digunakan untuk mengolah angka atau tabel, seperti $M s$. Excel. Google Slide digunakan untuk membuat presentasi, serupa dengan Ms. Power Point. (gambar 6)

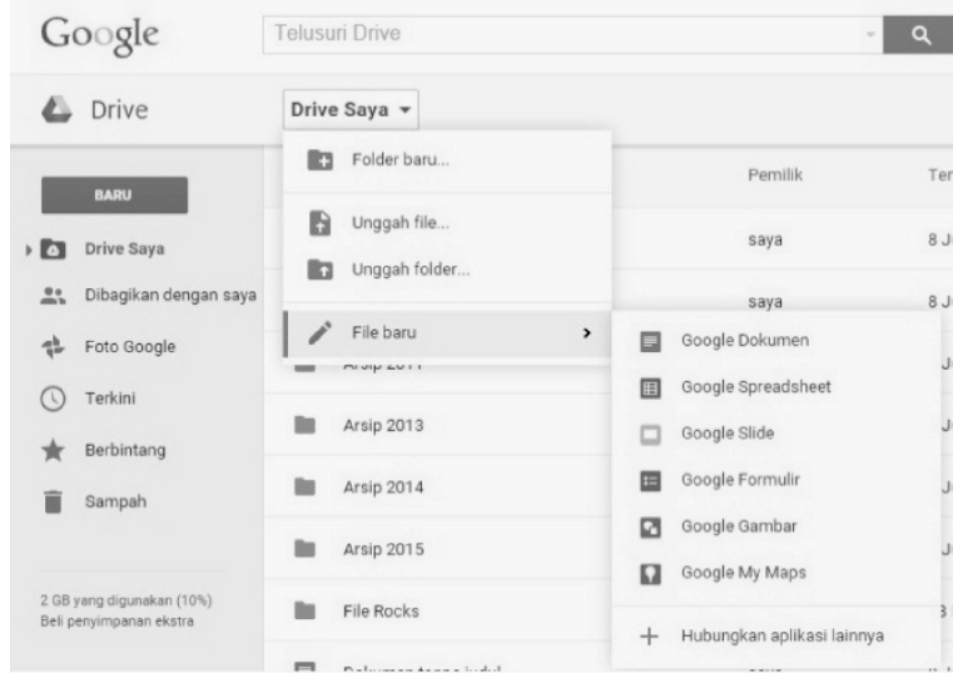

gambar 5. aplikasi dalam Google Drive

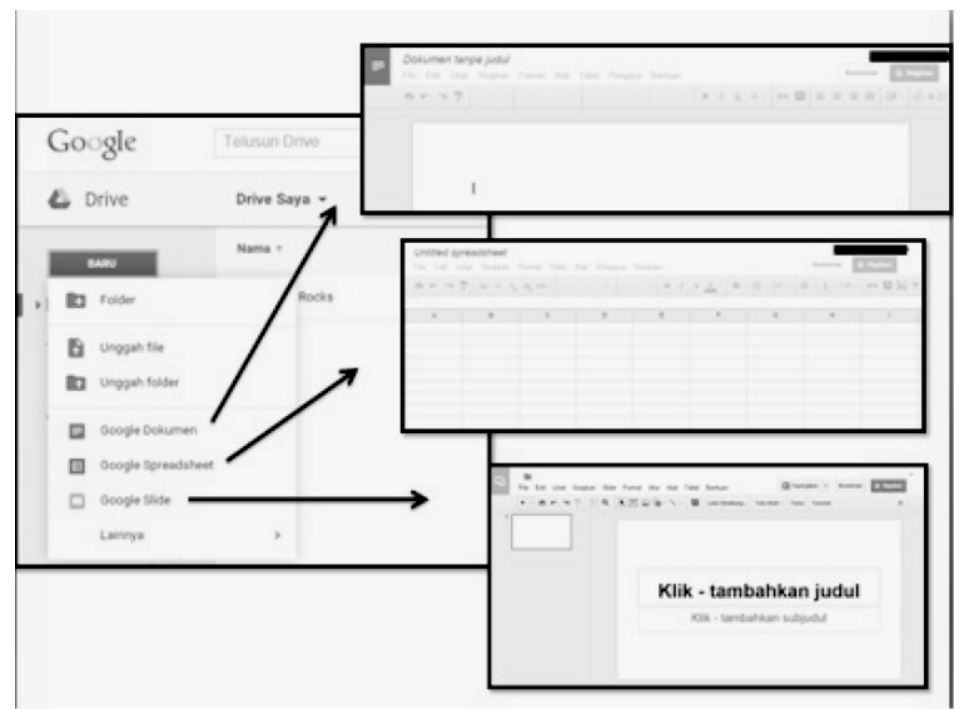

gambar 6. tampilan aplikasi pengelola data 
3. P engelola an arsip menggunakan Google Drive

Dalam aplikasi Google Drive, arsip yang sudah disimpan dapat diolah seperti yang diinginkan. Mengelola arsip yang berupa file di Google Drive $\mathrm{sangat} l \mathrm{ah} \mathrm{mudah}$. Contohnya ad alah mengarsipkan file pelajaran. Biasanya seorang pelajar menyimpan banyak sekali arsip yang digunakan untuk materi pembelajaran. Sering sekali penyimpanan file yang dilakukan hanya disimpan pada satu folder sehingga tidak tersusun rapi dan sulit untuk mencari kembali data-data yang dibutuhkan. Apalagi seorang pelajar pasti membutuhkan arsip yang mendukung evaluasi kegiatan yang telah dilakukan dalam proses $\mathrm{p}$ e $\mathrm{m} \mathrm{b}$ e 1 a j a $\mathrm{r}$ a $\mathrm{n}$. Permasalahan yang sering terjadi juga apabila ganti komputer maka kita akan merasa sulit untuk menemukan kembali file yang telah kita simpan dalam komputer sebelumnya, karena file yang dibutuhkan harus dipindahkan . Terbatasnya ruang dan waktu dapat menyebabkan kurang efektif dalam pencarian arsip tersebut. Dengan a danya permasalahan tersebut maka sangat diperlukan penyimpanan arsip yang menggunakan sistem anytime, anywhere dan retrieval system salah satunya adalah Google Drive. Berikut adalah simulasi pengelolaan arsip yang berbentuk file di Google Drive.

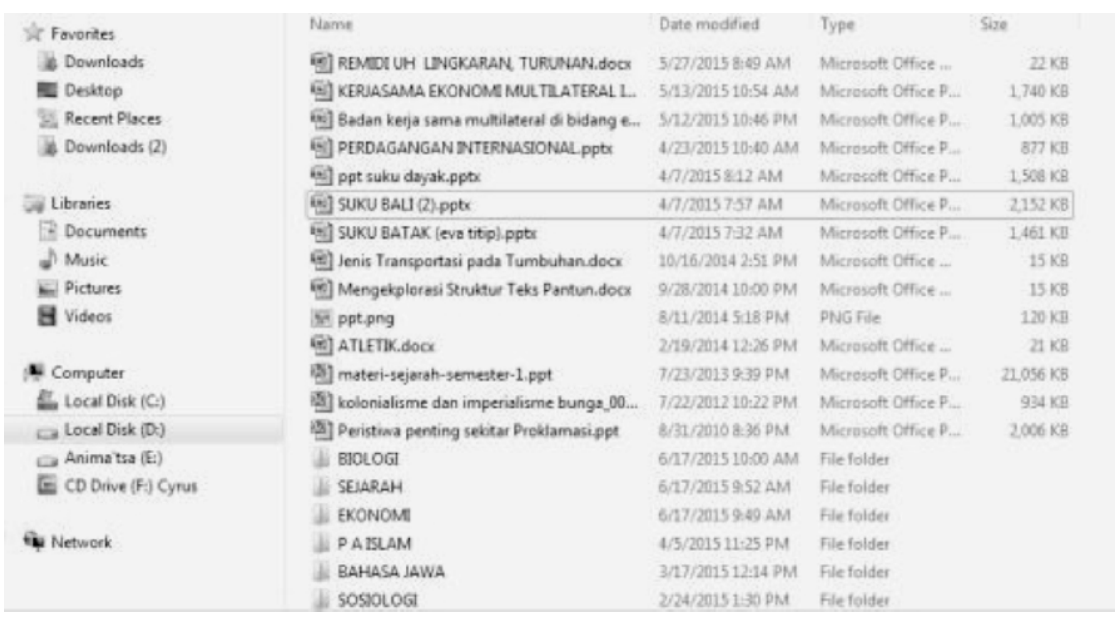

gambar 7. arsip dalam bentuk file yang disimpan dalam folder komputer 


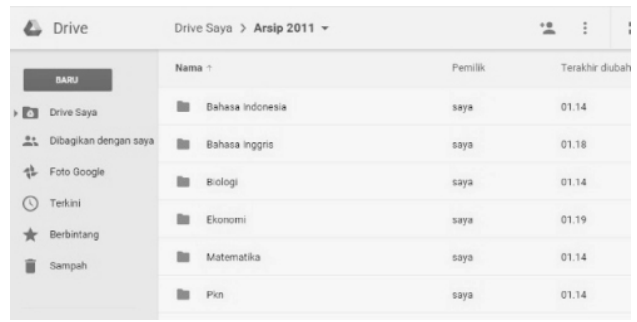

gambar 8. arsip yang disimpan

di Google Drive

Keunggulan dari Google Drive adalah arsip akan mudah diakses setiap saat, $\mathrm{m} \mathrm{e} \mathrm{miliki} s p a c e$ penyimpanan yang besar, dan edit arsip yang berbentuk dokumen secara simultan. Dalam Google Drive memungkinkan para pelajar berbagi arsip, $\mathrm{s}$ e h i ng a s a ngat memudahkan apabila seseorang meminta arsip tersebut tanpa harus mengantarkan arsip tersebut. Apabila arsip tersebut bersifat rahasia atau pribadi, Google Drive juga memberikan jaminan keamanan. Selain itu $\mathrm{t}$ e $\mathrm{rd} \mathrm{a} \mathrm{pat} \mathrm{m}$ e d i a penyimpanan virtual yaitu dapat menyimpan berbagai bentuk arsip film, $P D F$, foto, audio dan lain-lain.

Google Drive ini memiliki keterbatasan di antaranya adalah apabila tidak terkoneksi dengan jaringan internet, arsip tidak bisa terbuka. Kapasitas peyimpanan hanya $5 G B$, jadi apabila ingin menyimpan arsip yang sangat banyak harus membeli untuk menambah kapasitas penyimpanan. Terkadang artikel yang kita buat sekarang baru terindeks beberapa menit bahkan sampai berhari-hari. Google Drive tidak bisa mengindeks halaman tertentu, sehingga dalam menggunakan Google Drive diusahakan untuk menyimpan arsip yang sangat penting, masih digunakan dan masih sering dibuka sewaktu-waktu.

\section{F. Penutup}

\section{Kesimpulan}

Penyimpanan arsip berbentuk file yang disimpan dalam laptop atau netbook dengan memiliki resiko yang besar. Dengan cara menggunakan Goggle Drive yang sangat membantu pelajar dalam penyimpanan arsip secara anytime dan anywhere. Dengan pentingnya Google Drive, perlu penerapan untuk para pelajar tentang prinsip, stimulasi pengolahan dan penyimpanan data.

\section{Saran}

P e r 1 u a d a n y a pengembangan dan sosialisasi kepada para pelajar untuk menggunakan Google Drive sebagai media penyimpan arsip secara retrieval system. Media ini 
lebih baik dala m menyimpan dan mengelola arsip bagi para pelajar karena Google Drive diharapkan mampu mengatasi permasalahan kearsipan oleh pelajar secara aman, efektif dan efisien. Selain itu, perlu ada penelitian lanjutan untuk melebihbaikkan penelitian in i karena adanya keterbatasan kapasitas penyimpanan arsip dalam Google Drive.

\section{DAFTAR PUSTAKA}

Edar Santoso. "Arsip: From Problem to Solution". Buletin Kearsipan Sahifah, 2014, halaman 6.

Setyawati Nukuk Dwi Hastuti. "Pengelolaan Dokumen". Buletin Kearsipan Sahifah, 2014, halaman 18.

Sulianto, Joko. "Implementasi Paikem dengan Media Google Drive pada Mata Kuliah Pembelajaran Geometri dan Pengukuran". http://prosiding. upgrismg.ac.id/ index.php/ mbs_2013/mbs_13/paper/view/3 32/284. Semarang. Diakses 02:06 Rabu 08-Juni-2015.

$\mathrm{Vis}$ i $\mathrm{I} n \mathrm{form}$ a $\mathrm{ika}$. http://googleapps.visioinformati ka.com/kelebihan-google-Drive 